\title{
Yours for Liberty: \\ Women and Freethought in Nineteenth-Century Iowa
}

\author{
JOANNE PASSET
}

"FOR A NUMBER OF YEARS I have been scattering Infidel literature," wrote Cornelia Boecklin from Burlington, Iowa, in 1885 , "\& I sincerely hope that it has helped." In addition to placing copies of such pamphlets as "God and the State" and "An Anarchist on Anarchy" on the counter of a local stationery store and at the Knights of Labor meeting hall, the zealous promoter of independent thought also wrote dozens of letters for publication in such freethought periodicals as Fair Play, Truth Seeker, and Lucifer, the Light-Bearer (the titles of which were intended to capture the movement's commitment to equality, justice, and truth). ${ }^{1}$

Boecklin was just one of the late nineteenth-century Iowans who saw freethought as an important venue for the agitation for women's rights. Women would never achieve equality, they argued, so long as the church and the state relegated them to a subordinate status. Distanced from the thousands of women who joined the Woman's Christian Temperance Union (WCTU) because they rejected Christianity, Boecklin and other female

\footnotetext{
I would like to thank the individuals who served as referees for the Annals of Iowa, as well as its editor, for valuable suggestions and constructive criticism. I also wish to acknowledge the assistance of reference librians at the Burlington Public Library, the Clinton Public Library, and the State Historical Society of Iowa.

1. Cornelia Boecklin to Joseph Labadie, $1 / 27 / 1885$ and 2/9/1885, Labadie Collection, Special Collections Library, University of Michigan, Ann Arbor.
}

THE ANNALS OF IOWA 63 (Spring 2004). (C) The State Historical Society of Iowa, 2004. 
freethinkers also avoided woman suffrage associations because they believed that securing the vote would be pointless until people had been taught to think for themselves. Using the lecture circuit in tandem with print culture, freethinking women constituted an important dimension of the nineteenth-century movement for women's rights, one that had a significant presence in Iowa and the Midwest.

The portrayal of female freethinkers in works of women's history perpetuates the image of freethought as a movement that appealed primarily to privileged women living in the northeastern United States. As Kathi Kern argues in Mrs. Stanton's Bible, New York suffragist Elizabeth Cady Stanton not only offered a devastating critique of Christianity, but also maintained close relationships with noted atheist lecturer Robert G. Ingersoll and freethought editor B. F. Underwood. Moreover, notes Kern, other advocates of women's rights also participated in the Free Religious Association and the American Secular Union; the membership of those organizations came "mainly from middle-class intellectuals in the Northeast-radical Unitarians, transcendentalists, scientists, members of the liberal professions, and women's rights advocates." ${ }^{2}$

Freethinkers are largely absent from published histories of women because Stanton and Susan B. Anthony wanted to exclude the free-love scandals of the 1870s (and the freethinking women who were involved in them) from their five-volume History of Woman Suffrage. To some extent, historian William Leach remedies this omission in True Love and Perfect Union when he discusses freethought's relevance to nineteenthcentury women who sought to rationalize sexual desire; however, his research is with few exceptions based on the experiences of women in New England and the mid-Atlantic states. ${ }^{3}$ To counter this trend, historians have produced case studies documenting midwestern women's activism. Historians Louise Noun and Rachel Bohlmann, for instance, emphasize the activism and nonconformity of Iowa women such as Annie Savery,

2. Kathi Kern, Mrs. Stanton's Bible (Ithaca, NY, 2001), 59, 63-64.

3. William Leach, True Love and Perfect Union: The Feminist Reform of Sex and Society, 2d ed. (Middletown, CT, 1989), 7, 86, 153. 
yet do not consider freethought's role in disseminating ideas about women's equality and rights. ${ }^{4}$

Female freethinkers do appear in national studies exploring the history of women in socialism and free love, yet those works tend to reinforce an image of freethought as a marginalized movement with minimal impact. Likewise, histories of the free love movement include female freethinkers, but usually because they were the wives or daughters of periodical editors. Histories of woman suffrage by Ellen DuBois, Eleanor Flexner, and Aileen S. Kraditor further minimize the significance of freethinkers by omitting entries for freethought and related terms from their indexes, even when the texts include discussions of freethinking women such as Frances Wright, Matilda Joslyn Gage, and Ernestine Rose. Such treatment suggests to readers that freethinkers either had no involvement with the women's rights movement, had minimal impact on it, or were exceptions rather than the rule. ${ }^{5}$ In The Grounding of Modern Feminism, Nancy Cott offers a broad interpretive framework for understanding how the concept of feminist consciousness emerged from an array of nineteenth-century movements for women's rights. National in scope, her study highlights the need for local studies that can shed light on how specific nineteenth-century

4. Louise R. Noun, Strong-Minded Women: The Emergence of the Woman-Suffrage Movement in lowa (Ames, 1969); Louise Rosenfield Noun with Rachel E. Bohlmann, Leader and Pariah: Annie Savery and the Campaign for Women's Rights in Iowa, 1868-1891 (Iowa City, 2002); Diana Pounds, "Suffragists, Free Love, and the Woman Question," Palimpsest 72 (1991), 10-13.

5. Mari Jo Buhle, Women and American Socialism, 1870-1920 (Urbana, IL, 1981), briefly discusses German freethinkers. Ellen Carol DuBois includes free lovers Matilda Joslyn Gage and Ernestine Rose in Feminism and Suffrage: The Emergence of an Independent Women's Movement in America, 1848-1869 (Ithaca, NY, 1978) and Woman Suffrage and Women's Rights (New York, 1998). Linda Gordon considers the experience of freethinkers who were active in the free love movement in The Moral Property of Women: A History of Birth Control Politics in America, 3d ed. (Urbana, IL, 2002). Nonconformist women, but not specifically freethinkers, are treated in Barbara Cutter's Domestic Devils, Battlefield Angels: The Radicalism of American Womanhood, 1830-1865. Freethinkers are virtually absent in Ruth Bordin, Woman and Temperance: The Quest for Power and Liberty, 1873-1900 (New Brunswick, NJ, 1990); Sara M. Evans, Born for Liberty: A History of Women in America, reprint ed. (New York, 1997); and Aileen S. Kraditor, The Ideas of the Woman Suffrage Movement, 1890-1920 (New York, 1981). 
social movements, such as freethought, contributed to twentiethcentury feminist identity. ${ }^{6}$

Like historians of women, historians of freethought minimize the movement's significance to women, but they do so by focusing on the activities of male leaders at the national level. Of the biographical sketches included in Samuel P. Putnam's 400 Years of Freethought, for instance, only 11 percent are of women. One reason men such as Putnam failed to recognize women's more widespread involvement is that he and other male leaders regarded women's religiosity (membership in churches and such organizations as the WCTU) as a major obstacle to the formation of a rational state. Although male leaders of freethought organizations worked to unchain women from "the shackles of Christian belief," their inherent distrust of women kept them from adopting a woman suffrage plank. ${ }^{7}$

Some women did join state and national freethought organizations, but in order to comprehend the extent of the movement's appeal, we must look to the grassroots level. ${ }^{8}$ Print culture - in this case, freethought periodicals-is critical to recovering women's involvement in the freethought movement and its

6. Nancy F. Cott, The Grounding of Modern Feminism (New Haven, CT, 1987), 810, 42. For discussions of free love and freethought, see John C. Spurlock, Free Love: Marriage and Middle-Class Radicalism in America, 1825-1860 (New York, 1988); Martin Henry Blatt, Free Love and Anarchism: The Biography of Ezra Heywood (Urbana, IL, 1989); and Hal D. Sears, The Sex Radicals: Free Love in High Victorian America (Lawrence, KS, 1977).

7. The quote is from Evelyn A. Kirkley, Rational Mothers and-Infidel Gentlemen: Gender and American Atheism, 1865-1915 (Syracuse, NY, 2000), xii. The most recent works on the history of freethought are Susan Jacoby, Freethinkers: $A$ History of American Secularism (New York, 2004); and Joanne E. Passet, Sex Radicals and the Quest for Women's Equality (Urbana, IL, 2003). Earlier works include Samuel P. Putnam, 400 Years of Freethought (New York, 1894); Albert Post, Popular Freethought in America, 1825-1850 (New York, 1943); Sidney Warren, American Freethought, 1860-1914 (New York, 1943); Martin E. Marty, The Infidel: Freethought and American Religion (Cleveland, OH, 1961); Fred Whitehead and Verle Muhrer, eds., Freethought on the American Frontier (Buffalo, NY, 1992). First published in the Index (a publication of the Free Religious Association) in 1872, the "Nine Demands of Liberalism" address such issues as taxexempt status for churches, Sunday closing laws, and prayer in public schools.

8. Jill Ker Conway discusses the need to examine such vanished segments of American history in "Utopian Dream or Dystopian Nightmare? NineteenthCentury Feminist Ideas about Equality," Proceedings of the American Antiquarian Society 96 (1986), 287. 
significance for them because it was through print that women encountered freethought ideas and interacted with other freethinkers. For this essay, I examined freethinkers' letters to such periodicals as Boston Investigator, Fair Play, Foundation Principles, Freethought, Truth Seeker, and Lucifer, the Light-Bearer.'

Employing a reader-centered approach, and using Iowa as a case study, I argue that exposure to freethought ideas through lectures and print culture empowered women to question prevailing customs and laws governing their daily lives. A few became lecturers, but many others exercised agency by writing for publication. Forming interpretive communities with other readers of freethought periodicals, they exchanged ideas about such topics as reproductive health, sexual abuse, and contraceptives. ${ }^{10}$ The arrest and prosecution of editors who published their words heightened women's awareness that their emancipation was inextricably connected to the freedom of speech and the press and prompted them to take action. Creating homes in which their children could grow up free from the orthodox influences that pervaded local communities, Iowa mothers, daughters, sisters, and wives became agents for the transmission of freethought ideas to the next generation.

There are several reasons why Iowa is an excellent field for a study of women and freethought at the grassroots level. In the last quarter of the nineteenth century, Iowa became a prominent field for freethought activity as westward migration caused freethought's center of gravity to shift from the East Coast to the

9. I have been able to find some biographical data on some of the correspondents in manuscript census records, county histories, and city directories. As for the editors of the publications, Edwin C. Walker and Lillian Harman edited Fair Play from Valley Falls, Kansas, and Sioux City, Iowa. Lois Waisbrooker published Foundation Principles from her home in Clinton, Iowa, until she moved to Antioch, California, and Topeka, Kansas. Moses Harman began Lucifer, the Light-Bearer, in Valley Falls, Kansas, in 1883, but moved his editorial offices to Topeka, Kansas, and Chicago before ceasing publication in 1907. The Truth Seeker began in Paris, Mlinois, in 1873, but then moved to New York City, where it was published continuously into the twentieth century. Microfilm copies of these periodicals and incomplete print runs are available at the Kansas State Historical Society, the Library of Congress, and the Wisconsin Historical Society. 10. According to historian Elizabeth Long, Book Clubs: Women and the Uses of Reading in Everyday Life (Chicago, 2003), 8-10, print-based interpretive communities develop because readers often "need the support of talk with other readers." 
Midwest and West. By 1893, for instance, Iowa ranked second in the United States (after California) in membership in the Freethought Federation." Second, the activities of Iowans who formed numerous local leagues or societies are well preserved in reports they wrote for the freethought press. Third, itinerant lecturers who traveled through Iowa wrote regular columns in which they recorded their impressions of the freethinkers they encountered there. Finally, the letters of dozens of Iowa freethinkers are preserved in a variety of freethought periodicals.

\section{LATE NINETEENTH-CENTURY FREETHOUGHT was an} amorphous social movement championing "freedom of thought against all dogma, creed, or confession of organized Christianity." Its adherents ranged on a spectrum from the antireligious to those who professed "a private unconventional faith revering some form of God or Providence but at odds with orthodox religious authority." ${ }^{12}$ The movement had been part of American life since the late eighteenth century. During the period often referred to as the Second Great Awakening, its advocates "moved out of formal movements into quiet private pursuits," but a second generation of freethinkers arose in reaction to "revivalist excesses." Some eastern freethinkers, especially the transcendentalists, were seen as an alternative to (rather than an enemy of) religion; others-for instance, Frances Wright and Robert Dale Owen-moved west and adopted a more militant stance toward Christianity. Several thousand Americans identified themselves as freethinkers in antebellum America, but the many short-lived associations and publications freethinkers initiated subsided during the Civil War, as did the activities of numerous other reform movements. ${ }^{13}$

11. In 1879,44 percent of National Liberal League auxiliaries were in the Midwest; by 1884 the number had increased to 58 percent. See Proceedings of the Third Annual Congress of the National Liberal League, 1879, 101-6; and The 1884 Truth Seeker Annual and Freethinkers' Almanac, 44-48. For Freethought Federation statistics, see Truth Seeker, 11/4/1893, 697. Iowa had 350 members.

12. Kirkley, Rational Mothers and Infidel Gentlemen, xii; Jacoby, Freethinkers, 4.

13. Martin E. Marty, "Free Thought and Ethical Movements," Encyclopedia of the American Religious Experience: Studies of Traditions and Movements, ed. Charles H. Lippy and Peter W. Williams, 3 vols. (New York, 1988), 2:731-40. 
Following the war, a number of factors combined to threaten Protestant hegemony, among them industrialization, urbanization, and immigration, the spread of Darwinism, the rise of Spiritualism, the visibility of noted atheist lecturer Robert G. Ingersoll, and even author Samuel Clemens's literary attack on the church. ${ }^{14}$ In time, growing numbers of Americans experienced a crisis of faith as they attempted to reconcile Protestant teachings with the changing world, leading some to question the authority of the church and its relationship to the state. ${ }^{15}$ Organizing in order to have a voice in political matters, postbellum freethinkers (who sometimes called themselves liberals to distinguish themselves from their antebellum predecessors) established the Free Religious Association (1867), the National Liberal League (1876), which became the American Secular Union in 1885, and the Freethought Federation in 1892. Drawing inspiration from deists Thomas Paine, Thomas Jefferson, and James Madison, these advocates of mental liberty embraced science and rationalism as the solution to nineteenth-century social ills. Many were active in other reform movements dedicated to freedom; thus, freethinkers shaped and were shaped by such related causes as antislavery, women's rights, free love, and Spiritualism. Calling for a strict separation of church and state, postbellum freethinkers expressed concern about such issues as the Sunday opening of fairs and museums, the tax-exempt status of religious groups, and prayer in public schools. In the last third of the nineteenth century, state and local freethought organizations proliferated, the freethought press flourished, and thousands of Americans heard about freethought from itinerant lecturers. Freethinkers were so active that historians have labeled this era the "Golden Age of Freethought."

IOWA WOMEN came to freethought from diverse backgrounds. Young, old, single, married, widowed, and divorced, they ranged economically from farm women familiar with the im-

14. Ibid. Spiritualism became especially popular among women struggling to cope with the wartime loss of brothers, sons, and fathers. See Ann Braude, Radical Spirits: Spiritualism and Women's Rights in Nineteenth-Century America (Boston, 1989).

15. See Paul A. Carter, The Spiritual Crisis of the Gilded Age (DeKalb, IL, 1971). 
pact of drought, oppressive monopolies, and economic depressions and working-class women who fought passionately to free themselves from wage slavery to the wives of merchants and professionals who had the money and the leisure time to immerse themselves in radical causes. Predominantly EuroAmerican, freethinkers had roots in utopian and antislavery movements yet expressed nativist concern about the late nineteenth-century influx of Catholic immigrants. Most stood apart from the woman suffrage movement and the Woman's Christian Temperance Union because of their agnosticism, atheism, or embrace of Spiritualism. A few were raised as freethinkers, but many others as young women had left the Methodist, Seventh Day Baptist, Quaker, or other such religious denominations when they became interested in Spiritualism, and that movement led some to freethought.

Several movements had prepared the way for Iowa women to respond positively to freethought by promoting independent thinking and action. The first, hydropathy (more commonly known as water-cure), stressed women's health, education, and self-reliance. It laid the foundation for challenging authority, in this case, of the medical profession. In addition to teaching the importance of such preventative health measures as cold-water treatments, exercise, and diet, water-cure physicians empowered women by giving them information about their bodies, especially gynecological matters. Historians of the water-cure movement have focused on treatments given in health resorts in New England and the Middle Atlantic states, leaving the impression that it was an eastern movement favored by such privileged women as Harriet Beecher Stowe. Yet thousands of Americans learned about this alternative system of treatment through the Water-Cure Journal (established in 1844). A reader living in Maquoketa reported in 1855, "There is scarcely a cottage here in which your journals are not attentively perused." Itinerant health lecturers also carried the liberating gospel of this reform movement to rural women and men. Struggling with a heavy trunk filled with anatomical lantern slides, M. Augusta Fairchild traveled by foot and stage through cold water and miles of mud in 1864 to reach Iowa audiences. Mothers, she reported, were eager to improve their health and that of their 
families because they had "lost all confidence in doctors and their drugs." Lecturers also encouraged women to further exercise agency by traveling east to train at a hydropathic college so they could return to their hometowns to provide residents alternatives to the medical monopoly. After returning from her year of training, DeWitt resident Juliet $\mathrm{H}$. Stillman took great delight in seeing her patients "throw off the old shell and come forth new creatures." ${ }^{16}$

A second movement, dress reform, encouraged women to challenge the authority of fashion. Closely linked to the watercure movement, leaders of the dress reform movement believed that women would be healthier and could move more freely if they ceased wearing lung-constricting corsets and wore shortened skirts and trousers. Amelia Bloomer, for whom this style of dress is named, settled in Council Bluffs in 1855, and as early as 1858 , twenty single and married Iowa women boldly proclaimed themselves dress reformers in the Sibyl, a nationally circulated journal devoted to the cause of dress reform. When farm woman Phebe Palmer delivered a paper about healthful dress at a meeting of the Low Moor Farmer's Club (in Clinton County) in 1863, she linked the freedom to dress in a healthful way to other freedom-seeking causes: as a member of the Eden Meeting of Progressive Friends, she opposed chattel slavery, participated in the underground railroad, and supported woman suffrage. ${ }^{17}$

16. "An Iowa Agent," Water-Cure Journal, June 1855, 124; M. Augusta Fairchild, M.D., "Slough," Herald of Health, June 1864, 234-35; J. H. Stillman, "Experiences in Hygeio-Therapeutics," Water-Cure Journal, May 1860, 70. Stillman's ad for her water-cure practice appeared in the DeWitt Standard, 1/16/1861. According to Susan E. Cayleff, Wash and Be Healed: The Water-Cure Movement and Women's Health (Philadelphia, 1987), 27, the Water-Cure Journal circulated to 50,000 subscribers by December 1852, and had a far wider readership because subscribers routinely shared issues with friends and neighbors. For more on the water-cure movement, see Jane B. Donegan, Hydropathic Highway to Health: Women and Water-Cure in Antebellum America (Westport, CT, 1986).

17. "Dress Reform in Iowa," Water-Cure Journal, November 1854, 108; "List of Dress Reformers," The Sibyl, 9/1/1858, 421; Noun, Strong-Minded Women, 4953. For more on the social, cultural, and religious significance of the dress reform movement, see Gayle V. Fischer, Pantaloons and Power: A NineteenthCentury Dress Reform in the United States (Kent, OH, 2001). As historian Louise Noun has documented in Strong-Minded Women, 16-17, 49-53, lowans wore the bloomer as early as 1851 in Dubuque, Muscatine, Ottumwa, and Farmington. A 
Finally, Spiritualism worked in conjunction with hydropathy and dress reform to encourage women to be independent in thought and action. The word Spiritualism evokes images of Victorian women and men summoning spirits while seated in a darkened room, yet as a religious response to the mid-century crisis of faith, Spiritualism "held two attractions that proved irresistible to thousands of Americans: rebellion against death and rebellion against authority." In addition to comforting women who mourned the loss of husbands, fathers, and sons during the Civil War by offering them the possibility of communicating with the deceased, it appealed to women who "felt oppressed by the traditional roles assigned them" and who blamed churches for perpetuating oppressive practices. Indeed, many Spiritualists were devoted to such causes as the abolition of slavery and the reform of marriage, prisons, and the medical profession. $^{18}$

Generally eschewing formal organizations, Spiritualists participated in this movement by attending camp meetings, listening to itinerant lecturers, and sharing ideas through letters written to dozens of periodicals. As historian Ann Braude convincingly argues, rural as well as urban women flocked to Spiritualism by the thousands, finding their voices and even their life's work as mediums and healers. Lecturer Juliet Stillman Severance, a Spiritualist since her year of medical study in New York City, set out across Iowa in the summer of 1870 "to preach the gospel [of Spiritualism], heal the sick, and delineate character." Following in the wake of the noted Spiritualist lecturer E. V. Wilson, she declared his message "the perfect breaking plow" for "meeting the ignorance and bigotry of [religious] orthodoxy." Hoping to have a lasting impact, she encouraged local

perusal of the Water-Cure Journal uncovers more examples of Iowa women who wore the boomer: in Westville and in or near Low Moor and in Cedar, Johnson, Lee, Linn, Marshall, Tama, and Winneshiek counties. Sarah Howe, of Burlington, demonstrated additional initiative, selling patterns for the bloomer costume through the mail as late as 1886. For her ad, see Lucifer, the Light-Bearer, 11/12/ 1886, 4. See also Louise Noun, "Amelia Bloomer: A Biography," Annals of Iowa 47 (Winter 1985), 575-617, and (Spring 1985), 575-619.

18. Braude, Radical Spirits, 2 . Spreading quickly from its beginnings in upstate New York in 1848, Spiritualism reached the Midwest via lecturers (especially mediums) and print culture. 
women to organize Spiritualist societies and children's progressive lyceums to carry on the work in their communities.

In the early 1870 s Spiritualism splintered into two factions: a larger and more affluent group stressed the movement's Christian identity and focused on the phenomenon of communicating with the dead, while a freethinking faction identified with the controversial Victoria Woodhull and championed such causes as labor reform and third-party political activism. Some Iowa Spiritualists repudiated Woodhull and her co-worker Moses Hull (a former Adventist minister who left his wife of many years to live with a younger woman) because of their sexually liberated views, while others declared that they saw "nothing wrong, lewd, or demoralizing in anything written or taught in Woodhull and Claflin's Weekly. ${ }^{\prime 20}$ Tensions erupted again in July 1875 when two thousand women and men attended the State Association of Spiritualists meeting in Dubuque. Christian Spiritualists sang "Nearer My God to Thee" at a meeting where Mattie Hulitt Parry pronounced herself an "unchristian Spiritualist" and a Mrs. Fay declared that the mission of Spiritualism was "to redeem woman and save man." According to a biased reporter from the Dubuque Times, "a strong smell of sulfur" (alluding to Satan) pervaded the camp. Despite differences of opinion, the association maintained a free platform so that all viewpoints could be heard and people could decide for themselves. Thus, audiences gained exposure to anarchists, dress reformers, freethinkers, marriage reformers, medical reformers, and others who questioned the authority of

19. Juliet Stillman Severance lectured on Spiritualism and health reform in Cedar Rapids, Des Moines, DeWitt, Dubuque, Fort Dodge, Iowa Falls, Marshalltown, and many other small towns and villages made accessible by rail. For details of her travels as a Spiritualist missionary, see "Letter from Mrs. Juliet H. Stillman Severance," Religio-Philsophical Journal, 6/11/1870, 1; 7/9/ 1870,$8 ; 8 / 20 / 1870,2 ; 10 / 1 / 1870,6$. Examples of groups organized by women include the First Spiritualist Association of Des Moines and its flourishing Progressive Lyceum for Children, described in Religio-Philosophical Journal, $1 / 23 / 1869,8$.

20. "Iowa Spiritualists," Religio-Philosophical Journal, 11/1/1873, 8; E. A. Davis, "Spiritualism in Iowa," Woodhull \& Claflin's Weekly, 8/23/1873. For references to Woodhull's visits to lowa during the early 1870 s, see "Lecture Engagements," Woodhull \& Claflin's Weekly, 2/7/1874, 8; "Victoria C. Woodhull in the West," ibid., 2/14/1874, 10. For an in-depth look at Iowa reactions to Woodhull, see Pounds, "Suffragists, Free Love, and the Woman Question," 10-13. 
church, state, patriarchy, and the professions. This reputation for openness distinguished Iowa Spiritualists from many of their East Coast brethren and shaped the context in which freethought would spread throughout the state. ${ }^{21}$

Iowans interested in Spiritualism's reformatory promise could learn more by reading books and tracts offered for sale by itinerant lecturers and sold through the offices of Spiritualist periodicals. Lois Waisbrooker, a Spiritualist who lectured in Iowa during the 1860 s and 1870 s before moving there from Ohio in the 1880 s, found a ready audience for her self-published works when she lectured in Independence, Waterloo, and Waverly. At the same time, she began cultivating an audience for the journals (Our Age, Foundation Principles, and Clothed With the Sun) she would edit in later years. ${ }^{22}$ Shaped by encounters with rural midwesterners, her Spiritualism was tinged with freethought, antimonopolism, and land reform. The spirit world, she believed, depended "upon us for its essential elements"; therefore, Spiritualists should work for the abolition of monopolies because no "set of men has the moral right to hold land not in actual use from those who need it." A letter from Mrs. L. B. Childs, written two decades later from Council Bluffs, testifies to the geographic and chronological reach of Waisbrooker's words. Even then, she believed, every man and woman would benefit from reading them. ${ }^{23}$ Like Waisbrooker, Juliet Stillman Severance had several of her most popular talks, including $A$ Lecture on the Industrial and Financial Problems and A Lecture on Religious, Political, and Social Freedom, reproduced in pamphlet form and

21. Descriptions of the 1875 Spiritualist camp meeting are from the Dubuque Times, 7/2-4/1875, 7/7 1875. The figure of 2,000 attendees is from Truth Seeker, 10/30/1875, 259. For additional accounts, see "The Dubuque Camp Meeting: A Word about Management," Religio-Philosophical Journal, 7/31/1875, 156; and "Several Rows in the Camp," Religio-Philosophical Journal, 7/31/1875, 158.

22. The Clinton city directory for $1884-85$ lists Waisbrooker as editor and publisher of Foundation Principles. She served for a year in the early 1890 s as acting editor of Lucifer. No issues of Our Age, which she edited from Michigan, appear to be extant.

23. Foundation Principles, 10/20/1886, 3; Mrs. L. B. Childs, letter to the editor, Foundation Principles, February 1894, 4. Extant copies of Foundation Principles edited from Clinton in 1886 are difficult to locate. The University of Michigan owns one issue. Waisbrooker describes her travels in Iowa in "From Louis [sic] Waisbrooker," Religio-Philosophical Journal, 9/9/1871, 6. 
offered them for sale at ten cents each. Spiritualist O. P. Burnham explained, after hearing Severance speak, that he intended to use her pamphlets to convert his neighbors in Ames, Iowa: "There are so few progressive minds around me," he complained, "that I get faint."

Such Spiritualist weeklies as Woodhull E Claflin's Weekly (published by free lovers Victoria Woodhull and her sister Tennessee Claflin from 1870 to 1876) and New Thought (published by Moses Hull and Mattie Sawyer in Maquoketa in 1886 and two years later in Des Moines) also played a vital role in nurturing Iowans' interest in Spiritualism as a social reform movement by fearlessly publishing discussions of "live issues." Unlike the more conservative Banner of Light (Boston) and Religio-Philosophical Journal (Chicago), reform-oriented Spiritualist publications often were short-lived because they lacked financial stability. In order to make ends meet, editors resorted to such revenuegenerating activities as job printing, serving as book agents, and even taking in boarders. ${ }^{25}$ Soliciting contributions for type, ink, and paper from readers, the publishers provided their readers with concrete ways of supporting the Spiritualist movement.

Iowa women alleviated their cultural and geographic isolation by forming interpretive communities with other readers of Spiritualist periodicals. In addition to writing letters for publication, they also exchanged private correspondence with other readers and occasionally arranged to meet. For some, Spiritualist periodicals became vehicles for the construction of one's identity. An enthusiastic Fort Dodge subscriber to both Woodhull \& Claflin's Weekly and The Word (an anarchist, free love periodical edited by Ezra H. Heywood), for instance, informed readers of The Word that she had taken as her personal motto Patrick Henry's declaration, "Give me liberty or give me death." For others, periodicals edited by reform-minded editors such as Woodhull

24. [O. P. Burnham], "Voices from the People," Religio-Philosophical Journal, 9/30/1871, 6 .

25. Hull and Sawyer previously had edited Hull's Crucible, devoted to Spiritualism and radical reform. In 1860 Hull, an Adventist minister, lived in Marion County, Iowa, with his second wife, Elvira, and their three daughters. See 1860 manuscript population census, Knoxville Township, Marion County, Iowa. Hull became a companion to Mattie Sawyer in 1872. For more information, see "Biography of Rev. Moses Hull," The Psychic Era, March 1902, 1-10. 
and Claflin provided opportunities to engage in discussion of such controversial subjects as free love, infanticide, and marital sexual abuse. As the numbers of women who shared similar views grew locally, they formed clubs (in order to secure better subscription rates to periodicals) and in some instances organizations. Inspired by Woodhull's example, a Clayton County contributor boasted that Elkader had established a free-love league with twenty members, "pretty good for a little town of less than one thousand. ${ }^{26}$ In this context freethought took root and grew.

INFORMED BY THEIR ENCOUNTERS with hydropathy, dress reform, and Spiritualism, Iowa women responded enthusiastically to freethought lecturer Edwin Walker's 1878 call for a mass meeting of freethinkers to be held in Des Moines. They began to envision themselves as part of a broad-based network of activists linked by their common goals and by the print culture that kept them informed of each other's activities. Those who attended this first meeting of the Iowa Liberal League recognized Walker's leadership by electing him secretary. From its inception, however, female participants defied the stereotype of women as enslaved by religious superstition by playing a variety of leadership roles. ${ }^{27}$ The league's first constitution stipulated that there be "an agent in each county in the State, whose duty it will be to immediately associate with ... two other residents of the county ... to take charge of the work ... and assist in the organization of local leagues. ${ }^{\prime 28}$

Eager to begin the work, women across the state organized local auxiliaries, hosted meetings, served as officers, and deliv-

26. The Word, May 1873, 3; Woodhull \& Claflin's Weekly, 8/30/1873, 7. The Brooks family is enumerated in the 1870 manuscript population census, Webster County, Fort Dodge, Third Ward. For examples of topics discussed, see Woodhull \& Claflin's Weekly, 9/13/1873, 13; ibid., 3/21/1874, 3-4; ibid., 1/16/1875, 6 ; ibid., $9 / 27 / 1873,11$. For census data on the Comstock family, see the 1870 federal population census entry for A. J. Comstock, Oskaloosa Township, Mahaska County, p. 333.

27. Walker was a book dealer and teacher from Florence, lowa. For more on the meeting, see E. C. Walker, "Mass Convention of Iowa Liberals," Truth Seeker, 2/16/1878, 108; and "Iowa Convention," Truth Seeker, 3/30/1878, 203.

28. "Organization," Truth Seeker, 2/2/1878, 76. 
ered papers they had written. They also instituted lyceums for children and wrote accounts of lecturers' visits to their communities for publication in freethought journals. As noted lecturer Mrs. H. S. Lake observed, such activities were "of a very practical kind," not only because they promoted the spread of freethought in the state, but also because they reinforced a sense of community among geographically dispersed freethinkers. ${ }^{29}$

Seeking an opportunity to associate with other lowans who shared an interest in Spiritualism and the freedom of religion and thought, one hundred women and men gathered in Ottumwa in the fall of 1882 to charter the Iowa Conference of Spiritualists. From its inception, this association was known for its commitment to the free exchange of ideas. Members purchased twenty acres in Clinton for a campground, and by 1885 had reincorporated as the Mississippi Valley Spiritualist Association. Camp meetings, held each August at the association's Mount Pleasant Park, attracted devoted Spiritualists as well as curiosity seekers and others in search of pleasant entertainment and sociability. At a time when eastern Spiritualist camp meetings increasingly denied radical reformers access to their platforms, the Mount Pleasant Park Camp Meeting remained committed to preserving a free platform and tolerating topics deemed "unwelcome" at other camp meetings. In addition to musical entertainment, daily lessons on physical culture, and evening séances, attendees in 1889 could hear such lectures as "Shall this Nation be Christianized" and "Is Marriage a Failure?"30

29. Boston Investigator, 2/8/1882, 6. Mattie Parry (later Krekel) spoke at the Des Moines meeting, Maria L. Follett (of LeClaire) served as assistant secretary, and Ella J. Skinner was elected to the executive committee. Irene Wagner, of Florence, hosted the organizational meeting of the state's first league in her home on January 19,1878, and agreed to serve as treasurer. Katie Kehm publicized activities of the Ottumwa Liberal Society in the Truth Seeker. Shenandoah's Mrs. B. E. Holcomb held meetings in her family's store and organized a committee to send personal invitations to people suspected of having liberal tendencies. Cornelia Boecklin served as treasurer of the Burlington Liberal League (est. 1882) and hosted liberal lecturers such as Britain's Annie Besant. See "Iowa Convention," Truth Seeker, 3/30/1878, 203; Truth Seeker, 10/2/1886, 635; Mrs. B. E. Holcomb, Freethought, 3/10/1888, 119; Truth Seeker, 4/22/1882, 254.

30. Sarah Jane Kimball recorded her impressions of the camp meeting in her diary, 8/26/1883, Sarah Jane Kimball Papers, State Historical Society of Iowa, Iowa City. For more extensive reports of Spiritualist camp meetings held at Mount Pleasant Park in 1889, see Clinton Daily Herald, 7/19, 22, 23, 24, 26, 27, 
Freethought lecturers canvassed Iowa during the 1880s, a decade punctuated by economic fluctuations, labor unrest, and drought, speaking to increasingly receptive women and men who gathered in tents, groves, schoolhouses, and private homes. Initially, some lecturers found it difficult to support themselves in the state, but by 1886 American Secular Union president Samuel P. Putnam pronounced Iowa "one of the best territories for the pioneer of freedom. Its broad and breezy territories do not take to [religious] orthodoxy." Other nationally prominent lecturers, including John E. Remsburg and W. S. Bell, made frequent stops in the state, delivering talks bearing such titles as "Sabbath-Breaking" and "The Glory of Infidelity" as they traveled along the Iowa Central, Chicago, Burlington, and Quincy, and other railways. ${ }^{31}$

After completing a 132-day lecture tour of the state in 1881, Iowa Liberal League secretary Edwin Walker concluded that the experience had been one of "hard work, small pay, many frowns, but some warm smiles, cordial hand-clasps, and earnest good speed." Despite hardships of travel—cold rooms for sleeping, mud-encrusted roads, and long waits. for freight trains-he and others felt encouraged by the people they encountered who were "alive to the necessity for constructive work" and "not ashamed to be known as Infidels," a nineteenth-century label often applied to agnostics and atheists. Putnam reported similar

29,30 , and $31 / 1889$, and $8 / 1,2,6,8,9,10,12,13,15,17$, and 20/1889; and Moses Harman, "Campmeeting Notes," Lucifer, 8/30/1889, 2. Iowa Spiritualists and Freethinkers had joined forces as early as 1879 . For reference to Spiritualists extending "a cordial invitation to all Free-thinkers to meet with them," see "The Society of Progressive Spiritualists, Cedar Rapids," Religio-Philosophical Journal, 5/31/1879, 4 .

31. For the economic hardships lecturers encountered, see "For Iowa Liberals," Truth Seeker, 4/9/1881, 235; Samuel P. Putnam, "News and Notes," Truth Seeker, 4/10/1886, 229; and "Mrs. Freeman's Adventures," Truth Seeker, 3/24/1888, 180. Putnam assessed Iowa as a field for lecturers in 400 Years of Freethought (New York, 1894), 550-52, 580. Based on his travels, Putnam pronounced Burlington, Correctionville, Cromwell, Des Moines, Fort Madison, Hamburg, Ottumwa, Shenandoah, Waverly, and West Union to be the "chief localities for liberalism in Iowa." Lecturers' titles are from Truth Seeker, 10/23/1886, 682-83. For advertisements mentioning railways, see Truth Seeker, 12/2/1882, 760; and ibid., 11/17/1883, 725. According to Truth Seeker, 8/5/1893, 489, John Remsburg had just delivered 37 lectures in Iowa in 30 days. Minnie Geier described W. S. Bell's lectures in Truth Seeker, 1/21/1893, 44. 
experiences when touring the state later that year. In Randalia, for instance, he praised the Carter family, especially the senior Mrs. Carter, for the "fearless expression of unpopular opinions and earnest propagandism of the religion of humanity." Such women, he informed Truth Seeker readers, show "what a woman can do," and "make victory certain." ${ }^{32}$

Female lecturers such as Marilla Freeman, Mrs. H. S. Lake, and Juliet Stillman Severance also found great favor with Iowa audiences in the 1880s and 1890s, in part because they had first earned reputations as lecturers on the Spiritualist circuit. An experienced speaker, Freeman could lecture for an hour without a manuscript, holding listeners "in that stillness that allows no word to be lost," as she delivered talks bearing such titles as "His Satanic Majesty" and "Orthodox Problems." Gender differences colored how audiences perceived speakers: they often commented on the substance of a male lecturer's talk and a female lecturer's appearance and delivery. Residents of Ottumwa, for instance, praised Freeman as "winsome and brainy," an "entertaining speaker, possessing a clear, distinct enunciation, a musical voice," and an "attractive presence."

Female freethinkers welcomed the opportunity to hear women lecturers because they were more willing than men to speak on topics relevant to women's lives. An audience of approximately 1,100 people, nearly half of them women, gathered at the Tama County fairgrounds in September 1882 to hear Juliet

32. Edwin C. Walker, "Minnesota Meanderings," Truth Seeker, 10/1/1881, 635; Samuel P. Putnam, "News and Notes," Truth Seeker, 12/10/1881, 794; ibid., $9 / 25 / 1886,612$. Walker's impressions of lowans are included in "Hawkeye Happenings," Truth Seeker, 7/2/1881, 427. In DeWitt, he found Elbridge and Polly Sweeting and their daughters "alive to the necessity for constructive work"; in Jackson County he encountered Mrs. Abbey and a carpenter's wife named Rachel Rosecrans, who were "not ashamed to be known as Infidels"; in La Motte he found Mr. and Mrs. A. L. Potter, Mr. and Mrs. Griffin, and Misses Vic and Metta Dalton "all ready to work for progress," as was a Nora Springs telegraph operator named Miss Cavanagh. Census data are available for Elbridge Sweeting, Clinton County, DeWitt Township; and Thomas Rosecrans, Jackson County, Farmers Creek, in 1870.

33. Truth Seeker, 2/9/1888, 154. For more on Mattie Freeman and Mattie Krekel, who entered the lecture circuit after the death of her husband, Judge Arnold Krekel, in 1888, see Annie Laurie Gaylor, ed., Women Without Superstition: "No Gods-No Masters": The Collected Writings of Women Freethinkers of the Nineteenth and Twentieth Centuries (Madison, WI, 1997), 629, 633. 
Severance, Mrs. H. S. Lake, and Nettie Pease Fox "fearlessly" discuss such "live issues" as obscenity, women's health, and social reform. They found Severance, in particular, to be an excellent orator, "vein-keen, cutting, humorous, radical, startling the timid" with her "bold flight along the dizzy pathways of forbidden themes, and shocking poor Mrs. Grundy almost out of her few remaining wits." Women who heard such speakers for the first time were thrilled to hear their thoughts and feelings expressed publicly. "Every fiber of my soul," confided Madrid's Abbie Culver after hearing Lois Waisbrooker speak in 1894, "vibrates in sympathy with your efforts to inform woman and elevate the standard of social purity." As women, they also appreciated the risks female lecturers took by speaking so frankly. "The worst possible construction," explained Mrs. F. E. P. Malcom, of Glidden, is "put upon whatever she may have to say and her character is assailed."

Female lecturers provided another valuable service when they carried announcements about births, marriages, deaths, and other newsworthy events from place to place. In this way, and through published accounts of their visits with families, they linked geographically dispersed freethinkers. After stopping with the Vincent family in Tabor during the winter of 1887, for instance, Lois Waisbrooker shared the sad news of Mary Sheldon Vincent's tragic death in a kitchen fire with subscribers to Foundation Principles. Readers across the nation recognized the Vincent name not only for its prominence within antislavery circles, but also because Mary Vincent coedited the American Non-Conformist with her husband James. ${ }^{35}$

Hosting a lecturer further reinforced a sense of community among rural freethinkers by transforming a woman's home, albeit temporarily, into a freethought salon. Even in cases where a husband and wife "were perfectly agreed in regard to theology,"

34. "The Tama Meeting," Truth Seeker, 9/23/1882, 603; Foundation Principles, 9/1/1894, 1; Lucifer, 9/22/1893, 3.

35. Foundation Principles, 12/1/1887, 2. More information about the family is available in the obituary of James Vincent Sr., Tabor Beacon, 12/8/1899. Both James and Mary Sheldon Vincent were graduates of Oberlin College and were enumerated, with their four sons, in the 1870 manuscript population census for Rawls Township, Mills County, Iowa. 
women such as Minnie Geier, of Union County, felt "utterly alone" because her closest freethinking friends lived so far away. But when a lecturer arrived, families traveled a dozen or more miles across the prairie to hear him or her speak and then remained in town for a day or two of social and intellectual interaction before returning home reinvigorated. ${ }^{36}$

When, for example, Marilla Freeman visited the William F. and Mary (Millisack) McCarroll family of Ottumwa in early 1888, she encountered Juliet Severance's son Frederick, schoolteacher and budding lecturer Katie Kehm, Industrial Appeal editor N. M. Ives, and two other families. The McCarroll family was noted for welcoming many freethought lecturers to their home in the $1870 \mathrm{~s}$ and $1880 \mathrm{~s}$. The granddaughter of antislavery pioneers Jacob and Sarah Millisack, Mary had observed her parents entertaining such abolitionist speakers as William Lloyd Garrison, Abby Kelly Foster, Wendell Phillips, and Frederick Douglass; after her marriage to William, a local merchant, she continued the tradition of reform-minded hospitality. ${ }^{37}$

Culturally marginalized, freethinkers also anticipated that a lecturer's visit would result in conversions that would yield more like-minded friends locally. In $1886 \mathrm{Mrs}$. L. L. Gustin wrote that her hometown of Fort Madison was "an orthodox town of the most pronounced type." "The few real Liberals of this town would hail with delight a Liberal lecturer who would stir up the slums of orthodoxy, and open the ideas of the people to the beauties of Liberalism. ${ }^{\prime \prime 38}$

AFTER A LECTURER'S VISIT and during the many months when weather made travel difficult, freethinkers relied on printed works to sustain their nonconformist views. While some families, such as Burlington's Werner and Cornelia Boecklin,

36. Minnie Geier reflected on her isolation in "Correspondence," Truth Seeker, $1 / 22 / 1892,60$. For more on the Geier family, see "News and Notes," Truth Seeker, 9/25/1886, 612; "Mrs. Freeman's Lectures," Freethought, 3/3/1888, 106; "News and Notes," Freethought, 9/29/1888, 469-70.

37. "Mrs. Freeman's Lectures," Freethought, 3/3/1888, 106-7; "Mrs. Freeman's Adventures," Truth Seeker, 3/24/1888, 181; History of Wapello County, Iowa, 2 vols. (Chicago, 1914), 2:155, 380-81.

38. Truth Seeker, 11/27/1886, 762. 
could afford a dozen or more titles, others struggled to afford one subscription, especially during periods of economic depression and drought. Ellen Armstrong, writing from Ottumwa, explained that she was barely able to "keep the wolf from the door" even though she worked "hard every day." Taking pity on this working woman, Lucifer, the Light-Bearer's editorial team sent issues gratis, but she refused their charity, explaining, "It will worry me so much to see it that I cannot enjoy reading it." Aware that editors of freethought periodicals operated on shoestring budgets, readers knew that prompt payment made the difference between a journal's survival and failure. ${ }^{39}$

Freethinkers began to view other readers of these periodicals as members of a freethought family (much as Spiritualists had done earlier), and derived great satisfaction from the exchange of published and private letters. A 50-year-old widow in Waverly, for instance, felt consoled and encouraged by her Lucifer friends when local residents criticized her failure to attend church and her decision to retain her previous husband's name after remarriage. Likewise, Ottumwa's Katie Kehm looked to her Truth Seeker family for support when "the jeers and taunts of Christian 'friends'" became "almost unendurable." And when Grinnell's freethinking physician Dr. Mary H. Aikin wanted to air her frustrations, she turned to readers of Lucifer and Fair Play. Some readers who despaired of finding like-minded mates in their communities also turned to freethought periodicals. Wapello freethinker Amanda Kremer placed an announcement in the Boston Investigator in November 1874. Subsequent correspondence with a Mr. Tallett led to a visit, marriage, and the couple's move to southern California, where they established a "liberal" home of their own.

Print culture also served as the primary tool for those who wished to proselytize on behalf of freethought. Aware that peo-

39. Lucifer, 6/14/1895, 4. "My husband," wrote Frederica de Crane from Orange City, Iowa, in 1889 when she sent her renewal, "says a Liberal is no Liberal if he don't pay for his Liberal paper." Lucifer, 12/6/1889, 3 .

40. Lucifer, 10/9/1883, 4; Truth Seeker, 11/27/1886, 763; Lucifer, 2/17/1888, 1. For other examples, see "Blunt Words on the Way," Fair Play, 8/10/1889, 3; and The Alarm, 9/15/1888. Aikin is listed in the Grinnell city directory from 1878 until 1894-95. The Kremer example is from Truth Seeker, 7/1/1875, 15. 
ple's fear of radical ideas would prejudice them against freethought literature, freethinkers adopted several creative strategies for introducing it to others. In Albia, Mary Clark took advantage of daily interactions with customers in her family's general store to distribute freethought pamphlets and periodicals. To those who would be "shocked" by Lucifer's frank discussion of sex reform, she gave the less sensational Fair Play. If people were reluctant to accept a paper from a "known radical," she sent their names to editors and asked that they send sample copies. "It seems to flatter some folks to think that 'some how they got a hold of my name.'" Another tactic was to place copies of freethought publications in parlors for guests to see and then freely loan them upon request. ${ }^{41}$

Freethinking women placed a high value on reading because they recognized the necessity of educating themselves in order to effectively enlighten others. Voracious readers, they looked to books as well as a wide array of periodicals to deepen their understanding of economic depressions, monopolies, corporate greed, patriarchal law, and religious teachings that relegated women to a subordinate status. A Creston laborer's wife named Rosa Evans, for instance, devoured such indictments of wealth and power as Thomas Carlyle's French Revolution, Rachel Campbell's The Prodigal Daughter, Lois Waisbrooker's The Next Revolution, and Ella Wheeler Wilcox's Gospel of Humanity, and then discussed them with other subscribers to freethought periodicals. ${ }^{42}$

Freethinking women further contributed to the social reproduction of freethought in the decoration of their homes. Instead of placing a Bible in her parlor, as did her neighbors, Florence Dutton transformed her Grand Mound farmhouse into an environment in which her family as well as her neighbors would daily be exposed to freethought ideals. In addition to decorating it with "pictures and mottoes upon the walls" and an array of freethought "books and papers upon the tables and

41. Mary Clark, "Answers to Circular Letter," Lucifer, 12/20/1889, 2. For a description of periodicals on display in Cornelia Boecklin's parlor, see Truth Seeker, 4/22/1882, 254.

42. Lucifer, 3/8/1895, 4; Fair Play, 3/8/1890, 68. Evans's husband is listed in the Creston city directory for 1883 . 
shelves," she also filled albums with autographs and photographs of the movement's heroes. ${ }^{43}$

GENDER TENSIONS characterized the freethought movement at the national level, but at least some of Iowa's married freethinkers strived to establish cooperative partnerships with their spouses. It was not unusual for a husband to describe himself as being "a 'woman's rights' man," or to explain that he supported free speech and a free press because they held the key to attaining women's rights. The male lecturers who often wrote about the men with whom they interacted also commented about wives who impressed them as "equally liberal." Samuel Putnam, for instance, attributed a Fayette County woman's progressive views to her habit of accompanying her husband on his travels. Wives also reported that they often read freethought texts aloud with their husbands and discussed the issues contained therein as intellectual equals. Married couples wrote to freethought periodicals independently of one another and made donations in their own names. Occasionally a husband or wife wrote to express a viewpoint the couple shared, but it was more common for one spouse to add a postscript to the other's letter. Although mothers often played a more active role in the education of their children, freethinking parents generally were of one accord when it came to raising their children to be independent thinkers. ${ }^{4}$

Placing their hope for a better world in the next generation, freethinking mothers believed it necessary to expose their children to freethought ideas early and often. From Leon, where her neighbors "neither want to read nor talk Liberalism," Ellen Long reported that she used Truth Seeker cartoons with her children to counter the religious ideas pervading the public school with its required prayer and Bible reading. In Northwood, a miller's wife named Annette Nye prepared her unmarried

43. E. C. Walker, "Hawkeye Happenings," Truth Seeker, 7/2/1881, 427. The Dutton family is enumerated in the 1880 federal manuscript population census, Olive Township, Clinton County, Iowa, p. 331C.

44. Lucifer, 11/26/1898, 383; ibid., 4/18/1903, 108; ibid., 11/8/1889, 3; ibid., 3/15/1895, 1, 4; Truth Seeker, 6/27/1885, 411; Lucifer, 12/17/1886, 4; ibid., 1/14/1887; ibid., 8/5/1887, 4; ibid., 3/7/1890, 3; "News and Notes," Truth Seeker, 10/8/1886, 628 . 
daughter to think and reason by providing her with choice articles from Lucifer, freethought novels, and health manuals. She ordered such books as Irene, or the Road to Freedom (a novel in which young women become economically self-sufficient and can marry for love instead of security) and Edward Foote's health manual Plain Talk. In addition, she decorated their home with photos of freethought heroes such as Lillian Harman (Moses Harman's daughter, who in 1886 served time in jail for contesting the Kansas marriage law, which stipulated that a couple must secure a license from the state before living together as husband and wife). ${ }^{45}$

Children who grew up in freethought families learned the importance of print culture because of its prevalence in their homes. Essays that children wrote for the Truth Seeker shed light on the importance of reading to a freethought family. "Papa and mamma spend most of Sunday reading the Truth Seeker," confided one seven-year-old correspondent. Another, the baby of her family, declared, "I hav [sic] four brothers and two sisters, all Liberals." On birthdays, they noted, their parents gave them as gifts freethought literature such as Susan Wixon's Story Hour or Elmina Drake Slenker's Little Lessons for Little Folks. ${ }^{46}$ Children's columns, which began appearing in freethought periodicals beginning in the mid-1880s, also filled an important function for parents who wished to counteract religious influences in their communities. By having their children write letters that editors of children's columns often published, mothers and fathers contributed to the construction of a print-based network that compensated for some of the ostracism children experienced locally. Parents also encouraged their children to choose poetry, essays about science, and moral tales from freethought

45. Ellen E. Long, "Anxious that Freethought Be Spread," Truth Seeker, 8/6/1892; Lucifer, 2/27/1887, 4. The Long family is described in Samuel P. Putnam, "News and Notes," Truth Seeker, 9/25/1886, 612. The Nye family is enumerated in the 1880 manuscript census of Northwood Township, Worth County. For other examples, see Lucifer, 6/17/1887, 4; and ibid., 1/20/1888, 4. All young men and women, wrote Maquoketa's Mary E. Preston, needed to have a copy of Irene so they would be better prepared for married life.

46. "Children's Corner Correspondence," Truth Seeker, 3/6/1886, 156; ibid., 5/1/1886, 284; ibid., 1/1/1887, 12; ibid., 2/14/1885, 107: For other examples, see ibid., 5/22/1886, 332; and ibid., 5/28/1887, 348 . 
children's literature for recitation at school. Reporting that she had recited a declamation titled "To the Priests, Greeting," one freethinker's child noted that church members in attendance thought the building "would be haunted for a year."

It is difficult to determine the long-term impact of women's efforts to instill freethought values in their children, but the example of Katie Kehm suggests that at least some remained committed to the cause into adulthood. Born in Warsaw, Illinois, in 1868 , Kehm declared herself a freethinker at 16 after observing struggling families who bore "the burden of an expensive church and clergy." By the time she graduated from Ottumwa High School in 1885, Kehm had become well known among the state's freethinkers because of her recitations, service as secretary of the Ottumwa Liberal Society, and contributions to the Truth Seeker. Taught to emphasize reason over emotion, she viewed the world with a critical eye and, as an adult, wanted to recruit women to counteract the "vast army of Christian women who, under the influence of priest or preacher, would destroy every vestige of Freethought." Marrying a freethinker, she moved to Oregon, where she became active in that state's liberal league and in organizing progressive lyceums for children (a freethought alternative to Sunday School). Kehm was just one of many young freethinkers whose marriage contributed to the construction of a kin-based network that reinforced interest in freethought. $^{48}$

WHILE SOME FREETHINKING WOMEN focused on raising children to think for themselves, others became devoted to the cause of sex education. They believed women would remain

47. Truth Seeker, 4/30/1887, 284. This child is not the same person as the adult Minnie Geier quoted earlier.

48. Truth Seeker, 10/2/1886, 635. I have not been able to locate Kehm in the federal population census, but some biographical information appears in Putnam, 400 Years of Freethought, 805-7. For additional insight into Kehm's beliefs and activities, see Truth Seeker, 11/27/1886; ibid., 7/16/1887, 458; ibid., 8/6/ 1887, 507. Her work in Oregon is described in Truth Seeker, 2/4/1893, 74. For another example of marriage between the children of freethinkers, see Putnam, "News and Notes," Truth Seeker, 10/8/1886, 628, in which he announces the marriage of Decatur County's John Long to one of W. S. Gammon's five freethinking daughters. Such unions ensured that there would be frequent opportunities to engage in discussion of liberal topics at family gatherings. 
oppressed so long as they were denied basic information about reproduction. Believers in hereditarianism (the concept that personality traits may be accounted for genetically), they argued that the conditions under which a child was conceived shaped the remainder of his or her life. Children fathered by abusive men, they believed, would be unnaturally aggressive and would have an insatiable sexual appetite. Too many parents, wrote Albia's Mary Clark in 1889, fail to instruct their children about the important subject of sexuality, yet "they will get instruction," and all too often it conveys an impression of the reproductive process as "nasty! nasty!" Noting that her medical practice had given her in-depth knowledge of "the torture some men's wives endure," Monona midwife Charlotte Luce argued that marital sexual abuse would continue so long as physicians taught men to regard sex as a physical necessity and the church taught them to consider it a marital right. ${ }^{49}$

Class differences surfaced when female freethinkers began debating the use of contraceptives. A shopkeeper's wife, Mary Clark, wrote disdainfully of "mothers and fathers low down in the scale of intelligence, who 'breed like rats." Considering herself more enlightened than those about whom she wrote, she confided in 1895 that "my companion and I have long been in favor of preventatives as a check to an ignorant, vicious population." Clark, who believed that poor mothers of large families were both uneducated and under the thumb of the church, proposed that "something more forcible than an invitation to use preventatives ought to be done." Others who shared her views distributed copies of books such as Edward B. Foote's Borning Better Babies (which advocated techniques for family limitation) to economically disadvantaged families. The key to reform was having fewer and healthier children; the means of accomplishing that goal, freethinkers argued, depended not on the use of contraceptives (an externally imposed form of control), but rather on striking "a responsive cord [sic] in the heart of a poor working man awakening to the fact he, through enslavement

49. Mrs. James F. Clark, "Friend Harman," Lucifer, 1/31/1890, 3; Mary Clark, "The Chiders Kindly Chidden," Lucifer, 10/11/1889, 2; Lucifer, 11/1/1889, 1. Anna Walton discusses the role of heredity in the transmission of character traits in Lucifer, 11/8/1889, 3. 
by the money and church power, has been deprived of his most valuable and sacred rights, namely to be well born." So long as such people were denied information about reproduction, correspondents elaborated, they would be kept in poverty and wage slavery. Working-class readers understood the logic of this argument, yet recognized that such changes would take a long time to accomplish. Until then, observed a machinist's wife from Creston in the 1890 s, married women would continue to resort to abortion "as a last and only hope of escaping the torture of having a large family to see in want and beggary."

Freethinking women who believed in the necessity of frank discussion of sexuality welcomed Moses Harman's 1886 adoption of a free-speech policy, in which he promised to publish letters verbatim, without censorship of any kind. They flooded his weekly with horrific accounts of gynecological ailments and abusive husbands. Drawing on her experiences as a medical practitioner, Monona midwife Charlotte Luce sent graphic letters describing husbands who tried to perform abortions on their wives, forced them to do arduous farm chores in bitterly cold weather during the early stages of labor, and demanded sexual satisfaction immediately following childbirth. Accused by male physicians of fabricating such accounts, Luce defended her testimonies by explaining that women felt more comfortable confiding in other women than in men. ${ }^{51}$

Harman's arrest and prosecution for violating the Comstock Act (prohibiting the distribution of "obscene" material through the mail) had a politicizing effect on women who read and wrote for his weekly. Freethinking women articulated their conviction that societal forces, especially the church, were conspiring to keep women in sexual ignorance. "The same spirit that nailed a Jesus to the cross, burned a Bruno [the Italian philosopher Giordano Bruno (1548-1600), who was martyred during the Inquisition for advocating Copernican theory] at the stake," declared Muscatine's Anna Clark Walton in late 1889, "is trying to silence by imprisonment those who have the courage

50. Mary Clark, "An Iowa Woman's Opinion," Lucifer, 3/15/1895, 1; "Hawkeye Happenings," Truth Seeker, 7/2/1881, 427; Lucifer, 11/8/1889, 3; ibid., 3/8/1895, 4; Fair Play, 3/8/1890, 68.

51. Lucifer, $11 / 1 / 1889,1$. 
to publish the unvarnished truth in behalf of the freedom of women. ${ }^{\prime 52}$

Rising to Harman's defense, Iowa freethinkers provided both moral and financial support because they valued the work he did and hoped to preserve Lucifer as a forum where they could discuss issues of importance to women. Denouncing Anthony Comstock as a "smut bag," Walton determined to do missionary work for the cause of free speech by distributing freethought pamphlets and copies of Lucifer. When a few readers expressed doubt about Harman's persistence in publishing content that resulted in his arrest, Mary Clark attacked those who would "rob generations yet unborn of the invaluable service he is rendering them, rob the wretched wives and mothers of the bravest, the most outspoken friend they have ever had, rob our rosy-cheeked daughters of one of the best educators of their future husbands." Mobilized to action, women collected signatures on petitions demanding his release, contributed donations ranging from ten cents to forty dollars for his legal defense fund, and even sent flowers to brighten his cell. Women did not let poverty keep them from lending their support: a weary Defiance woman, for instance, promised to "plant and tend a small [garden] patch," with the proceeds "to go to [the] Lucifer fund. ${ }^{\prime 53}$

SOME FREETHINKING WOMEN grew disillusioned with freethought when such nationally prominent, racially and socioeconomically privileged freethinkers as Robert Ingersoll and Samuel Putnam refused to call for repeal of the Comstock Act because they believed that advocating free speech would jeopardize their primary cause, the separation of church and state. Searching for solutions, some freethinking women turned to anarchism because of that movement's emphasis on individual liberty. Nationally, historians estimate, anarchists had approxi-

52. Ibid., 10/18/1889, 1. For more on Walton, see Muscatine County, Iowa, Graves Registration (Muscatine, 1939); and Muscatine city directories from 1879 through 1891-92.

53. Lucifer, 11/8/1889, 3; Mary Clark, "The Chiders Kindly Chidden," Lucifer, 10/11/1889, 2; Lucifer, 12/6/1889, 2; ibid., 1/5/1893, 4; "Greetings from Our Prisoner," Lucifer, 7/5/1895, 2; Lucifer, 10/29/1886, [3]; ibid., 11/26/1886, [3]; ibid., 5/24/1895, 4 . 
mately 50,000 adherents at their peak in the mid-1880s, but since they eschewed formal organization it is impossible to obtain exact numbers. Nonetheless, the movement appeared far larger and more threatening than numbers signify because of its visibility in such urban centers as Chicago and New York City. Anarchist periodicals such as Liberty (Boston), The Alarm (Chicago), and Free Society (Portland, Oregon, and Chicago) carried critiques of government and, like freethought periodicals, offered publications for sale. After devouring such works, Anna Walton concluded that she was no longer morally bound to obey laws she could not make. ${ }^{54}$

Although many freethinking women with anarchist leanings struggled to earn food and shelter, the Boecklins of Burlington represent a more affluent class of freethinkers. Born in New York in 1835, Cornelia married Swiss-born Werner Boecklin at 20 and moved west to Iowa after his discharge from the Union Army in 1864. In Burlington, Werner became a merchant affiliated with the Chicago, Burlington, and Quincy Railroad. In 1870 the Boecklins began building an elegant Swiss-style chalet on a lot owned by Cornelia's mother. Described by the Burlington Gazette as a "grand and imposing church," the Boecklin home and garden occupied an entire city block and is still standing today. It made a strong positive impression on freethought lecturer Mrs. H. S. Lake when she visited Burlington in 1882. "Their elegant home, filled with flowers, books, music, and plenty of cheer," was, she observed, "the center from which radiated, continually, an influence making for liberty, not only in religion, but in industry and social life."

During her 35-year residence in Burlington, Cornelia, an amateur botanist, delighted in filling their garden with exotic trees and shrubs. The house was filled with life even though only one of the couple's four children, Werner, survived. Raising

54. The Alarm, 1/19/1889, 3. As historian Wendy McElroy argues in Freedom, Feminism, and the State: An Overview of Individualist Feminism, $2 \mathrm{~d}$ ed. (New York, 1991), 3-26, the roots of American feminism are evident in individualist anarchism. For more on women and anarchism, see Margaret S. Marsh, Anarchist Women, 1870-1920 (Philadelphia, 1981).

55. Burlington Gazette, 5/21/1870, 4; Truth Seeker, 4/22/1882, 254. Werner Boecklin served as captain in New York's Nineteenth Infantry Regiment, mustering in during 1861 and resigning on July 7,1864. 
him "as a Liberal lad should go, unbiased by Sunday schools," Cornelia conducted a kindergarten for him and neighbor children in her home in the 1880 s. In that capacity, she served as a model of nonconformist womanhood for her student, Harriet Conner Brown, who, in describing her first day at the school, recalled the teacher's "queer" appearance in "long pantaloons of shepherd's plaid, topped by a full-skirted cutaway." ${ }^{156}$ An independent thinker, Cornelia saw no need to stand "with the majority." She attributed her outlook to "seeing and feeling the curse of the law." Even the sting of derision and criticism did not deter her from advocating radical causes ranging from dress and labor reform to free speech. "I go right ahead, do the best I can in my way, and don't care a snap what names I am called. ${ }^{\prime 57}$

Because Cornelia and her husband did not feel capable of lecturing to large groups, they devoted themselves to promoting freethought ideas among their friends and proselytizing with their pens. While Werner edited several short-lived papers (The Critic, The Evening Star, and Every Sunday Morning), Cornelia carried on an extensive correspondence with editors of and contributors to the numerous weeklies and monthlies she read. Wanting to advance freethought and anarchism, she also donated money for type, paper, and defense funds while distributing copies among her Burlington neighbors. Visitors to their home found in the parlor copies of such freethought and anarchist classics as Pierre-Joseph Proudhon's What Is Property and Henry George's Progress and Poverty and a wide array of radical periodicals, including The Alarm, Boston Investigator, Fair Play, Infidel Pulpit, John Swinton's Paper, Liberty, The Physiologist, La Revolte, Labor Leaf, Liberty, Lucifer, and Truth Seeker, and "any number of newspapers."

56. "Harriet Connor Brown Reminisces," pamphlet file clipping filed under "Burlington-Biography," Burlington Public Library.

57. Cornelia Boecklin to Joseph Labadie, 1/27/1885 and 4/29/1889, Labadie Collection.

58. History of Des Moines County and Its People, 2 vols. (Chicago, 1915), 441-42; Cornelia Boecklin to Labadie, 1/27/1885, Labadie Collection; Truth Seeker, $4 / 22 / 1882,254$. Boecklin discusses Proudhon and George in letters to Labadie dated $8 / 28 / 1885$ and 2/9/1885. According to the Boecklins, the most liberal of Burlington's local newspapers was the Morning Justice, published by the Knights of Labor. 
Whereas Luce, Walton, Clark, and other freethinkers believed the key to overall social reform lay in woman's sexual emancipation, Cornelia Boecklin criticized them for devoting too much time to the sex question. "You hear from me very rarely," she explained to Moses Harman in 1890, because "it is quite impossible for me to agree with you in looking upon the sex question as the question in the social muddle." Writing from the vantage point of an economically privileged woman who could retreat into her fine home and garden when Burlington residents criticized her appearance and beliefs, she considered the "sending of petitions and protests" a waste of time, "very much like Don Quixote's tilt against the windmill." Nor was she moved to tears by the publication of letters detailing "outrages perpetrated upon wives by wild beasts." She felt pity for the victims, but believed they must take steps to free themselves or the improvement would be only temporary. "A creature calling herself a woman having fifteen children by a wild beast is something beyond my comprehension," she wrote. "If she has not the physical nor the mental strength to 'herself strike the blow' for freedom it is a waste of time and energy trying to get the miserable victim out of the mire." Freethinkers would do better, Boecklin contended, to attack the root of the cause rather than to salvage the victims. ${ }^{59}$

Her privileged status may have influenced Boecklin's conviction that reformers should work for "man's material improvement" rather than for woman's sexual emancipation, but some working-class women shared her view. Alice, writing from Keokuk in 1893, acknowledged that the "'sex problem' troubles me very little." What disturbed her, she continued, was that "under this most pernicious and unjust economic system I have been robbed of the greater part of my earnings." Such resentment led her to accept the idea of a "bloody uprising of a long-suffering people" as the only corrective, and provided evidence for Boecklin, who declared anarchy more relevant to working people and women because it "means untaxed homes" and the security that leads to choice. Financially secure women, she believed, could choose to remain single or to leave abusive

59. In Boecklin's opinion, sexual abuse was just "one of the many rotten fruits of the same tree, the church, which is kept alive by that manure heap called the state." See Boecklin, "One of Many Bitter Fruits," Lucifer, 1/3/1890, 3. 
husbands. A dressmaker named Mattie Hursen, writing from Clinton, concurred: "She will be enabled, through her financial independence, to protect herself." ${ }^{\prime 60}$

In the mid-1880s the Knights of Labor offered reform-minded individuals such as the Boecklins an opportunity to exert political influence. When Cornelia joined the Women's Assembly of the Burlington Knights of Labor in 1885, she was pleased to discover that eight of the Assembly's original fifteen members were, as she described them, "known Infidels." As the Knights of Labor became more religious in form, if not in content, however, infidels such as Boecklin expressed their disgust with its "clap trap." By early 1887, the Assembly had disbanded. ${ }^{61}$

At the same time, the Boecklins grew disillusioned with freethought because it, as well as third-party political activism, was so slow to achieve results. Increasingly, she looked to anarchism and its more revolutionary demands. Canceling subscriptions to most of the freethought publications she and her husband had so generously supported, Cornelia explained,

Freethought papers in these days are principally intended for those individuals who are glad to leave the church to save paying pew rent. ... The state is our enemy; consequently, fight the state. ... it is a waste of time and energy to run "Secular Unions," "Liberal Leagues," and Freethought papers. When you start an anarchistic paper let us hear from you.

Yours for liberty. Cornelia Boecklin, Burlington, Jan. 19, 1888. ${ }^{62}$

After 35 years of agitation "with hand and pen," a tired and aging Cornelia Boecklin moved with her husband to their son's home in Passaic, New Jersey. "My hopes for better things in this world for the deserving are certainly not very sanguine," she confided to Michigan anarchist Joseph Labadie. "As to another world I know nothing, but I keep right along doing what seems to me best from my point of view. ${ }^{163}$

60. Lucifer, 8/25/1893, 3; Mattie Hursen, "Relations of Sexes," Lucifer, 3/25/1887.

61. Boecklin to Labadie, $2 / 9 / 1885$, Labadie Collection. For some insight into some of the conflicts the Knights of Labor encountered because of ceremonies with religious undertones, see Truth Seeker, 1/19/1889, 42.

62. Freethought, 2/4/1888, 63 .

63. For the Boecklins' final years, see Cornelia Boecklin, undated correspondence, Labadie Collection; and New York Times, 2/1/1953, 13. 
IOWA claims a host of remarkable nineteenth-century women, including such woman suffrage, dress reform, and temperance leaders as Carrie Chapman Catt, Amelia Bloomer, Annie Wittenmyer, and Annie Savery. It also was home to hundreds of freethinking women who, for the most part, have been excluded from histories of women. As the lives of such individuals as Cornelia Boecklin, Juliet Stillman Severance, Anna Clark Walton, and others confirm, their experiences contribute a new dimension to the history of nineteenth-century women's rights, the history of freethought, and the state's social and cultural heritage.

The antebellum spread of hydropathy, dress reform, and Spiritualism laid a critical foundation for Iowa women's acceptance of freethought ideas. When hydropathy and dress reform began to wane after the Civil War and when Spiritualism splintered in the early 1870s, nonconformist Iowans who wanted to agitate such "bread and butter" issues as antimonopolism, labor reform, and women's sexual emancipation moved to the freethought movement. The taint of free-love that accompanied them, especially when women pushed for repeal of the Comstock Act, created gender tensions in the movement nationally. Frustrated when national freethought organizations distanced themselves from morally controversial issues (usually issues most relevant to women), Iowa freethinkers such as Clinton editor Lois Waisbrooker and Burlington's Cornelia Boecklin turned to such third party political movements as the Knights of Labor, the Greenback Labor Party, and Populism. Those movements failing to satisfy them, especially when the economy worsened after the Panic of 1893, they increasingly found validity in anarchism's critique of power relationships.

Freethinking women's use of print culture and the lecture circuit contributed to the formation of a powerful network for the circulation of ideas shunned by the mainstream press. Periodicals, because they included reader correspondence, became the primary medium through which they advanced ideas about women's equality, constructed their identities, linked themselves to other freethinkers, and interacted. with family members and non-freethinking neighbors. Female freethinkers further extended their influence when they encouraged their children to 
read freethought themes at school and to question the beliefs of teachers and classmates. Such activities may or may not have led to conversions, but they did ensure that far more Iowansboth rural and urban-had some exposure to freethought ideas than previously acknowledged.

Drawn into the public arena as they challenged the power of the church to perpetuate the idea of women's inferiority, freethought women exercised agency by reading texts critically, sharing their ideas through letters written for publication, attending freethought lectures, donating money to freethought causes, attempting to interact with men as equals, and rearing children to be independent thinkers. Convinced that women's equality held the key to reform the world, they fought efforts to suppress the distribution of publications that contained sexual information and challenged institutions perpetuating the idea of woman's inferiority to man. Articulating ideas about freedom and equality within the privacy of their homes as well as from the podium and in the periodical press, Iowa's freethinking women had a lasting impact on themselves, their families, and the communities in which they lived. 
Copyright of Annals of Iowa is the property of State of Iowa, by \& through the State Historical Society of Iowa and its content may not be copied or emailed to multiple sites or posted to a listserv without the copyright holder's express written permission. However, users may print, download, or email articles for individual use. 